\title{
Kecernaan nutrien dan performa ternak babi fase starter yang diberi pakan campuran bahan pakan limbah
}

\author{
Majanto Ullo ${ }^{1}$, Sangle Yohannes Randa ${ }^{2}$, Sri Hartini ${ }^{2, *}$ \\ ${ }^{1}$ Alumnus Program Studi Pascasarjana Ilmu Peternakan, Universitas Papua, Manokwari, 98314 \\ 2Staf Pengajar Program Studi Pascasarjana Ilmu Peternakan, Universitas Papua, Manokwari, 98314 \\ *Correspondence: sri.hartini8877@gmail.com
}

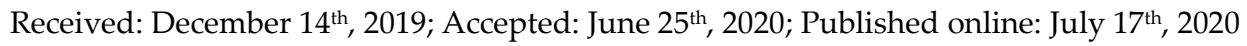

\begin{abstract}
Abstrak
Tujuan: Untuk mengkaji pengaruh campuran bahan pakan limbah terhadap kecernaan pakan, nutrien, dan performa ternak babi fase starter.

Metode: Rancangan penelitian yang digunakan adalah Rancangan Acak Lengkap dengan 4 perlakuan dan 3 ulangan. Perlakuan penelitian adalah: P0 (ransum komersial CP551 sebagai ransum kontrol), P1 (ransum campuran dari limbah ikan, ampas tahu, dan limbah sayur), P2 (P1 + dedak padi) dan P3 (P2 + kulit keladi). Penelitian ini menggunakan 12 ekor babi, umur 2 bulan dengan kisaran berat badan awal 5,49 sampai 9,20 kg (koefisien keragaman 16,37\%). Pakan penelitian diberikan selama 4 minggu. Variabel yang diukur meliputi rata-rata pertambahan bobot badan (PBB), konsumsi ransum, konversi ransum, total kecernaan pakan dan kecernaan nutrien (protein kasar, serat kasar dan energi metabolis).

Hasil: PBB dan konsumsi ransum ternak babi fase starter yang diberikan P1, P2, dan P3 lebih rendah dibandingkan P0, tetapi tidak terdapat efek signifikan terhadap konversi ransum. Pakan perlakuan tidak berpengaruh terhadap total kecernaan pakan, sedangkan efek pada kecernaan nutrien hanya didapatkan pada kecernaan serat kasar (SK). Ternak babi yang diberi P0, P2 dan P3 mempunyai kecernaan SK lebih tinggi dibandingkan P1.

Kesimpulan: Campuran bahan pakan limbah mempunyai efek negatif pada performa ternak babi fase starter tetapi tidak berdampak pada kecernaan pakan. Tingginya SK pada pakan limbah diduga menurunkan palatabilitas yang berdampak pada menurunnya konsumsi ransum dan PBB. Interaksi SK dengan komponen nutrisi lain dalam ransum dapat memodifikasi karakteristik fisik dan kimia dari serat kasar yang dapat berdampak pada kecernaan SK.
\end{abstract}

Kata Kunci: Babi; Kecernaan serat kasar; Palatabilitas pakan; Pertambahan bobot badan

\section{Abstract}

Objective: This study aimed to observe the effect of various combinations of by product feeds on feed and nutrient digestibility, and performance of starter pigs.

Methods: The experimental design was a Completely Randomized Design with 4 treatments and 3 replications. Treatment were: P0 (CP551 as a control diet), P1 (diets mixed of fish waste, tofu waste and vegetable leftovers), P2 (P1 + rice bran), and P3 (P2 + taro peelings). Twelve pigs at 2-months old 
with initial body weight about 5.49 to $9.20 \mathrm{~kg}$ (coefficient variance $16.37 \%$ ) were used in this study. The pigs were fed the experimental diets for 4 weeks.

Results: Body weight gain (BWG) and feed consumption of starter pigs given P1, P2, and P3 were lower than P0. However, there was no significant effect found on feed conversion ratio (FCR). Feed treatments did not affect total feed digestibility, nevertheless effect on nutrient digestibility was only found on crude fiber (CF). Pigs given P0, P2, and P3 had CF digestibility higher than P1.

Conclusions: By-product diets had a negative impact on the performance of starter pigs. However, it had no effect on feed digestibility. The high content of CF in by-product diets was suggested to reduce the feed palatability in which consequently reduced feed consumption and body weight gain. The interactions of an individual fiber with other feed components in a diet could modify its physicho-chemical property which could impact on CF digestibility.

Keywords: Body weight gain; Crude fiber digestibility; Feed palatability; Pig

\section{PENDAHULUAN}

Budidaya ternak babi bagi masyarakat Papua Barat khususnya di Kabupaten Manokwari bukan merupakan hal yang baru. Ternak babi bagi masyarakat Arfak di Kabupaten Manokwari mempunyai manfaat sosial yang beragam seperti antara lain; sebagai penentu status sosial, pembayaran mas kawin, pembayaran denda, maupun sebagai alat perdamaian bagi dua pihak yang bermusuhan [1,2]. Oleh karena itu pengembangan budidaya ternak babi di Kabupaten Manokwari mempunyai prospek yang cerah. Populasi ternak babi di Manokwari, sebagai ibu kota Provinsi Papua Barat, tercatat sebesar 34,994 ekor atau sekitar $38,06 \%$ dari total populasi ternak babi di Papua Barat [3].

Salah satu faktor yang memiliki pengaruh besar pada produktivitas ternak babi adalah pakan karena sebesar $60-70 \%$ dari total biaya produksi usaha peternakan babi berasal dari pakan [4]. Efektivitas pakan sangat bergantung pada kecernaan pakan yang secara langsung berpengaruh pada efisiensinya. Pada peternakan babi skala rumah tangga, umumnya pakan diberikan seadanya sesuai kemampuan peternak. Pakan yang banyak digunakan adalah pakan yang berasal dari limbah, antara lain; limbah pertanian, limbah perikanan, limbah hijauan asal pasar, maupun limbah industri kecil. Sering juga ternak babi hanya diberi batang pisang sebagai pakan utamanya [5]. Limbah hijauan asal pasar adalah sisa-sisa sayuran seperti antara lain; sayur kol, kubis, sawi, dan kangkung yang sudah tidak layak dijual maupun yang sudah tidak terpakai lagi [6]. Limbah ikan adalah limbah dari hasil kegiatan perikanan seperti antara lain; potongan daging ikan, sisik, dan insang [7]. Limbah industri kecil yang banyak digunakan sebagai pakan ternak babi adalah ampas tahu yang merupakan limbah dari pembuatan tahu. Ampas tahu umumnya masih mempunyai kandungan protein cukup tinggi namun serat kasar juga tinggi [8].

Serat kasar yang tinggi adalah ciri pakan asal limbah, oleh karena itu biasanya dilakukan pengolahan pakan sebelum diberikan kepada ternak. Namun pada masyarakat peternak skala rumah tangga umumnya pengolahan yang diberikan hanya dengan cara dimasak/direbus [5], sedangkan untuk dedak umumnya diberikan dalam bentuk kering.

Komposisi pakan ternak babi yang berasal dari bahan pakan limbah umumnya tidak sama antara satu daerah dengan daerah yang lain tergantung pada banyaknya ketersediaan bahan pakan limbah di daerah tersebut dan juga tergantung pada musim [5]. Di Manokwari, bahan pakan limbah yang banyak digunakan untuk pakan ternak babi antara lain; limbah ikan, ampas tahu, kulit keladi, dedak padi, dan limbah sayur. Produksi limbah sayuran dan limbah ikan di Manokwari secara berturut-turut berada dalam kisaran 2-11 dan 20-50 kg per hari [9]. Limbah-limbah tersebut mempunyai kandungan protein berkisar antara 4,26-31,21\%, kandungan energi bruto (GE) berkisar antara 3433-4951 $\mathrm{kkal} / \mathrm{kg}$, dan kandungan SK bervariasi antara 4-28,7\% BK [10]. Penelitian Hartini et al. [11] melaporkan 
bahwa penggunaan limbah-limbah tersebut dalam pakan oleh peternak babi di Manokwari adalah sebagai berikut; penggunaan limbah sayur sebesar $66 \%$, kulit keladi sebesar $60 \%$, ampas tahu sebesar $37 \%$ dan limbah ikan sebesar 26\%. Masyarakat peternak di Manokwari umumnya memberikan pakan kepada ternak babinya tanpa memperhitungkan kandungan nutrisinya. Penelitian ini dilakukan untuk mengetahui pengaruh pakan yang berasal dari komposisi berbagai bahan pakan limbah tersebut terhadap performa ternak babi fase starter, kecernaan pakan dan nutrien pakan.

\section{MATERI DAN METODE}

\section{Tempat dan waktu penelitian}

Penelitian ini dilaksanakan selama 4 bulan terhitung dari masa persiapan sampai pengolahan data bertempat di kandang peternakan babi Aro-M Bumi Marina Asri, Kecamatan Manokwari Barat, Desa Amban, Kabupaten Manokwari.

\section{Materi penelitian}

Materi penelitian adalah ternak babi betina persilangan babi Batam dan Australia berjumlah 12 ekor, umur 8 minggu dengan kisaran berat badan awal antara 5,49 kg - 9,20 kg (koefisien keragamanan 16,37\%). Ternak babi dialokasikan secara acak pada 12 unit kandang individual berukuran 2 x 1,5 $\mathrm{m} \times 1 \mathrm{~m}$ $(\mathrm{p} \times 1 \times \mathrm{t})$. Masing-masing kandang dilengkapi dengan tempat pakan dan tempat minum yang diikat pada salah satu tepi kandang sehingga tidak terbalik waktu babi sedang makan. Untuk ransum, bahan pakan limbah yang digunakan adalah limbah sayur, limbah ikan, ampas tahu, kulit keladi dan dedak padi. Limbah-limbah tersebut diperoleh dari pasar Wosi, pasar Sanggeng, industri tahu, industri keripik keladi, dan usaha penggilingan padi yang ada di Manokwari. Peralatan yang digunakan pada penelitian ini antara lain; timbangan digital gantung (Merk HBS, China) kapasitas $50 \mathrm{~kg}$ dengan tingkat ketelitian 10 gram untuk menimbang ternak, timbangan digital kapasitas $5 \mathrm{~kg}$ (merk CAMRY E.K-3650) dengan tingkat ketelitian 1 gram untuk menimbang ransum dan feses, kantong plastik sebagai tempat sampel, kamera untuk dokumentasi serta alat tulis menulis.

Tabel 1. Ransum perlakuan dan kandungan nutrisi

\begin{tabular}{lcccc}
\hline Bahan pakan/Ransum & P0 & P1 & P2 & P3 \\
\hline Pakan komersial (\%) & 100 & 0 & 0 & 0 \\
Limbah ikan (\%) & - & 41 & 38,12 & 36,6 \\
Ampas tahu (\%) & - & 14,35 & 22,83 & 21,5 \\
Dedak padi (\%) & - & 44,65 & 16 & 19 \\
Kulit keladi (\%) & - & - & 23,05 & 17,9 \\
Limbah sayur (\%) & - & - & - & 100 \\
Total (\%) & 100 & 100 & 100 & 91,24 \\
Perhitungan kandungan nutrisi (\%) & & & 3100 \\
Bahan kering & 87 & 91,13 & 91,06 & 19,50 \\
EM (kkal/kg) & 3100 & 3100 & 3100 & 2,22 \\
PK & 19,50 & 19,50 & 19,50 & 11,50 \\
Lemak & 4,00 & 2,37 & 2,19 & 23,64 \\
SK & 6,00 & 11,52 & 10,24 & 4,93 \\
Abu & 8,00 & 35,29 & 22,24 & 9,42 \\
Ca & 0,90 & 5,37 & 5,03 & 9,62 \\
Total P & 0,70 & 11,21 & & 3 \\
\hline
\end{tabular}

P0, CP 551 (ransum komersial); P1, ransum campuran 3 bahan pakan limbah (limbah ikan, ampas tahu, limbah sayur); P2, ransum campuran 4 bahan pakan limbah (P1 + dedak padi); P3, ransum campuran 5 bahan pakan limbah (P2 + kulit keladi). 
Proses penyiapan bahan pakan limbah

Ransum diberikan dalam bentuk kering. Selain dedak padi, semua bahan pakan limbah yang digunakan diproses sebagai berikut.

Limbah ikan yang digunakan berupa tulang, ekor, jeroan dan kepala ikan. Limbah ikan dibersihkan kemudian dikukus hingga matang dan dikeringkan dengan oven pada suhu $65^{\circ} \mathrm{C}$ selama $48-72$ jam sehingga didapat tulang dalam bentuk remah untuk selanjutnya digiling.

Limbah sayur yang digunakan adalah limbah sayur kangkung. Sayur kangkung dibersihkan terlebih dahulu dan dicincang \pm 1 $\mathrm{cm}$ kemudian dikukus agar tekstur lembek, dan dikeringkan di bawah sinar matahari, ditimbang lagi untuk mendapatkan berat kering dan kemudian dioven pada suhu $65^{\circ} \mathrm{C}$ selama 48-72 jam untuk selanjutnya digiling.

Limbah kulit keladi yang dikumpul dari industri pembuatan keripik dibersihkan, dikukus hingga lembek, ditiriskan, dan dioven pada suhu $65^{\circ} \mathrm{C}$ selama $48-72$ jam untuk selanjutnya digiling.

Limbah ampas tahu. Ampas tahu yang diperoleh dijemur di bawah sinar matahari, ditimbang lagi untuk mendapatkan berat kering dan kemudian dioven pada suhu $65^{\circ} \mathrm{C}$ selama 48-72 jam dan selanjutnya digiling.

Proses selanjutnya adalah menimbang masing-masing bahan pakan limbah sesuai dengan formulasi ransum perlakuan. Komposisi dan kandungan nutrisi ransum perlakuan dapat dilihat pada Tabel 1 .

\section{Rancangan penelitian}

Rancangan yang digunakan pada penelitian ini adalah rancangan acak lengkap (RAL) dengan 4 perlakuan dan 3 ulangan. Model matematika yang digunakan adalah:

$$
Y_{i j}=\mu+\alpha_{i}+\epsilon_{i j}
$$

Keterangan:

$$
\begin{aligned}
\mathrm{Y}_{\mathrm{ij}} & \text { : Hasil pengamatan } \\
\mu & \text { : Nilai rata-rata umum peubah yang } \\
& \text { diamati } \\
\alpha_{\mathrm{i}} & : \text { Pengaruh kombinasi berbagai } \\
& \begin{array}{l}
\text { bahan pakan limbah ke-i (P0, P1, P2 } \\
\text { dan P3) }
\end{array}
\end{aligned}
$$

eij : Galat percobaan pada perlakuan ke- i dan ulangan ke- $j(j=1,2,3)$.

\section{Ransum perlakuan}

Ransum perlakuan yang digunakan pada penelitian ini terdiri atas 4 ransum yaitu:

$$
\begin{aligned}
& \text { P0 } \text { Ransum komersial } 100 \% \text { (CP551, } \\
& \text { sebagai kontrol) } \\
& \text { P1 } \text { Ransum campuran dari } 3 \text { macam } \\
& \text { bahan pakan limbah (limbah ikan, } \\
& \text { ampas tahu dan limbah sayur) } \\
& \text { P2 : Ransum campuran dari } 4 \text { macam } \text { bahan pakan limbah (limbah ikan, } \\
& \begin{array}{l}
\text { ampas tahu, limbah sayur dan } \\
\text { dedak padi) }
\end{array} \\
& \text { P3 : Ransum campuran dari } 5 \text { macam } \\
& \text { bahan pakan limbah (limbah ikan, } \\
& \text { ampas tahu, limbah sayur, dedak } \\
& \text { padi dan kulit keladi) }
\end{aligned}
$$

Ransum disusun sesuai kebutuhan energi dan protein yang tertera pada label ransum CP551 yaitu kandungan energi metabolis (EM) sebesar $3100 \mathrm{kkal} / \mathrm{kg}$ dan kandungan protein kasar (PK) 19,50\%. Nutrien bahan pakan sesuai dengan hasil analisa yang dikemukakan oleh Lekitoo et al. [10]. Energi metabolis (EM) ransum ditentukan menggunakan persamaan Noblet and Perez [12] sebagai berikut:

$$
\begin{aligned}
\mathrm{EM}= & \mathrm{DE} \times(1,003-(0,0021 \times \% \mathrm{PK}) \\
\mathrm{DE}= & 4.151-(122 \mathrm{x} \% \mathrm{Abu})+(23 \times \\
& \% \mathrm{PK})+(38 \times \% \text { Lemak })- \\
& (64 \times \% \mathrm{SK})
\end{aligned}
$$

Keterangan:

$$
\begin{aligned}
& \text { DE : Digestible Energy (Energi tercerna) } \\
& \text { PK : Protein Kasar } \\
& \text { SK : Serat Kasar }
\end{aligned}
$$

Ransum perlakuan diberikan selama 4 minggu (28 hari). Sebelum ransum perlakuan diberikan, ternak terlebih dahulu diadaptasikan terhadap pakan perlakuan selama 1 minggu. Air minum diberikan ad libitum. Penerangan diberikan 24 jam/hari. Ransum penelitian diberikan setiap pagi dan sore pukul 06.00 dan 16.00 WIT, sisa pakan ditimbang setiap jam 20.00 WIT. 
Pengamatan pertambahan berat badan, konsumsi ransum dan konversi ransum

Penimbangan berat badan dan konsumsi ransum dilakukan saat awal penelitian dan setiap minggu selama 4 minggu. Data tersebut digunakan untuk menghitung Pertambahan Bobot Badan (PBB) dan total konsumsi ransum. Selanjutnya data PBB dan konsumsi ransum digunakan untuk mendapatkan nilai konversi ransum.

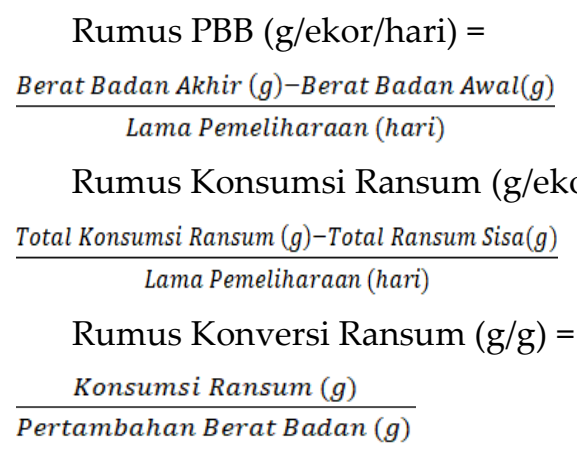

\section{Pengamatan total kecernaan pakan}

Total kecernaan pakan dan kecernaan nutrien dihitung menurut rumus dari Schneider and Flatt [13]. Total kecernaan pakan adalah selisih antara total pakan yang dikonsumsi (dalam BK) dengan total feses (dalam BK) dibagi total pakan dikonsumsi dikali $100 \%$ atau dengan rumus:

$$
\begin{aligned}
& \text { Total Kecernaan Pakan }(\%)= \\
& \frac{(\mathrm{TKR}-\mathrm{TF})}{(\mathrm{TKR})} \times 100 \%
\end{aligned}
$$

\section{Keterangan:}

$$
\begin{array}{ll}
\mathrm{TKR} & =\text { Total Konsumsi Ransum }(\mathrm{g}) \\
\mathrm{TF} & =\text { Total Feses }(\mathrm{g})
\end{array}
$$

\section{Kecernaan nutrien}

Kecernaan nutrien yang diamati adalah kecernaan PK, SK dan EM. Kecernaan nutrien didapatkan dengan rumus sebagai berikut:

$$
\begin{aligned}
& \text { Kecernaan Nutrien }(\%)= \\
& \frac{(\text { TKR X KNR)-(KNF X TF) }}{(\text { TKR X KNR) }} \times 100 \%
\end{aligned}
$$

Keterangan:

$$
\begin{aligned}
\text { TKR } & =\text { Total Konsumsi Ransum }(\mathrm{g}) \\
\text { KNR } & =\text { Kandungan Nutrisi Ransum } \\
& \text { (PK atau SK atau EM) }(\%) \\
\text { KNF } & \text { Kandungan Nutrisi Feses } \\
& \text { (PK atau SK atau EM) }(\%) \\
= & \text { Total Feses }(\mathrm{g})
\end{aligned}
$$

\section{Analisis data}

Data yang diperoleh dianalisa dengan analisa sidik ragam menggunakan program SPSS 16.0 [14]. Apabila didapatkan uji F berbeda nyata, maka dilanjutkan dengan uji Duncan Multiple Range Test (DMRT) untuk melihat perbedaan antar perlakuan. Taraf kepercayaan yang digunakan adalah 95\%.

\section{HASIL}

\section{Pertambahan bobot badan}

Pertambahan bobot badan (PBB) ternak babi fase starter yang diberikan perlakuan campuran bahan pakan limbah disajikan pada Tabel 2. Hasil penelitian menunjukkan bahwa pemberian campuran bahan pakan limbah (P1, P2, P3) menurunkan PBB ternak babi pada minggu ke 4 dan minggu 1-4 $(p<0,05)$.

Tabel 2. Pengaruh Perlakuan Pakan terhadap Pertambahan Bobot Badan Ternak Babi Fase Starter (g/ekor/hari)

\begin{tabular}{lccccc}
\hline \multirow{2}{*}{ Perlakuan } & \multicolumn{5}{c}{ Rataan PBB (g/ekor/hari) } \\
\cline { 2 - 6 } & Minggu 1 & Minggu 2 & Minggu 3 & Minggu 4 & Minggu 1-4 \\
\hline P0 & 275,24 & 334,76 & 369,52 & $545,24^{\mathrm{b}}$ & $381,19^{\mathrm{b}}$ \\
P1 & 94,29 & 79,29 & 45,72 & $200,00^{\mathrm{a}}$ & $91,61^{\mathrm{a}}$ \\
P2 & 103,33 & 93,33 & 42,38 & $153,34^{\mathrm{a}}$ & $98,10^{\mathrm{a}}$ \\
P3 & 39,05 & 41,90 & 79,05 & $50,52^{\mathrm{a}}$ & $52,63^{\mathrm{a}}$ \\
Total SEM & 41,149 & 50,041 & 57,230 & 66,390 & 49,099 \\
Nilai P & 0,202 & 0,100 & 0,079 & $0,003^{*}$ & $0,014^{*}$ \\
\hline
\end{tabular}

P0, CP 551 (ransum komersial); P1, ransum campuran 3 bahan pakan limbah (limbah ikan, ampas tahu, limbah sayur); P2, ransum campuran 4 bahan pakan limbah (P1 + dedak padi); P3, ransum campuran 5 bahan pakan limbah (P2 + kulit keladi). a-bSuperskrip yang berbeda di dalam kolom yang sama menunjukkan berbeda nyata, ${ }^{*} \mathrm{p}<0,05$. 
Tabel 3. Pengaruh perlakuan pakan terhadap konsumsi ransum ternak babi fase starter (g/ekor/hari)

\begin{tabular}{lccccc}
\hline \multirow{2}{*}{ Perlakuan } & \multicolumn{5}{c}{ Rataan Konsumsi Ransum (g/ekor/hari) } \\
\cline { 2 - 5 } & Minggu 1 & Minggu 2 & Minggu 3 & Minggu 4 & Minggu 1-4 \\
\hline P0 & $541,19^{\mathrm{b}}$ & $879,67^{\mathrm{b}}$ & $928,29^{\mathrm{b}}$ & $1202,70^{\mathrm{b}}$ & $887,96^{\mathrm{b}}$ \\
P1 & $228,00^{\mathrm{a}}$ & $399,52^{\mathrm{a}}$ & $496,46^{\mathrm{a}}$ & $618,38^{\mathrm{a}}$ & $432,20^{\mathrm{a}}$ \\
P2 & $180,57^{\mathrm{a}}$ & $301,24^{\mathrm{a}}$ & $489,48^{\mathrm{a}}$ & $432,02^{\mathrm{a}}$ & $350,83^{\mathrm{a}}$ \\
P3 & $148,67^{\mathrm{a}}$ & $325,82^{\mathrm{a}}$ & $474,95^{\mathrm{a}}$ & $417,94^{\mathrm{a}}$ & $341,84^{\mathrm{a}}$ \\
Total SEM & 52,893 & 88,402 & 71,259 & 115,03 & 80,536 \\
Nilai P & $0,004^{*}$ & $0,013^{*}$ & $0,013^{*}$ & $0,004^{*}$ & $0,003^{*}$ \\
\hline
\end{tabular}

P0, CP 551 (ransum komersial); P1, ransum campuran 3 bahan pakan limbah (limbah ikan, ampas tahu, limbah sayur); P2, ransum campuran 4 bahan pakan limbah (P1 + dedak padi); P3, ransum campuran 5 bahan pakan limbah (P2 + kulit keladi).

a-bSuperskrip yang berbeda di dalam kolom yang sama menunjukkan berbeda nyata, ${ }^{*} \mathrm{p}<0,05$.

\section{Konsumsi ransum}

Hasil penelitian menunjukkan bahwa pakan perlakuan berpengaruh nyata terhadap konsumsi ransum minggu ke 1, 2, 3, dan ke 4 $(\mathrm{p}<0,05)$. Ransum perlakuan juga berpengaruh nyata terhadap konsumsi ransum secara global (minggu 1-4) $(\mathrm{p}<0,05)$. Rataan konsumsi ransum ternak babi fase starter yang diberi perlakuan pakan yang berbeda disajikan pada Tabel 3. Uji lanjut Duncan menunjukkan bahwa konsumsi ransum ternak babi yang diberi pakan limbah lebih rendah dibandingkan dengan ternak babi yang diberi ransum komersial (Tabel 3).

\section{Konversi ransum}

Hasil konversi ransum ternak babi fase starter yang diberi perlakuan pakan yang berbeda dapat dilihat pada Tabel 4. Hasil penelitian mendapatkan bahwa perlakuan pakan tidak memberikan efek yang nyata terhadap konversi ransum baik secara mingguan (minggu 1, 2, 3, dan 4) maupun secara global (minggu 1-4).

\section{Total kecernaan pakan dan nutrien}

Total kecernaan pakan pada penelitian ini menunjukkan tidak berbeda nyata (Tabel 5). Hasil penelitian pada kecernaan nutrien hanya didapatkan berbeda nyata pada kecernaan SK ( $\mathrm{p}<0,05$, Tabel 5). Hasil uji lanjut Duncan menunjukkan bahwa nilai kecernaan serat kasar P0 tidak berbeda dengan P2 dan P3, tetapi berbeda nyata dengan P1.

\section{PEMBAHASAN}

\section{Pertambahan bobot badan}

Rendahnya PBB ternak babi yang diberi pakan asal limbah dibandingkan dengan ternak babi yang diberi ransum komersial diduga karena pakan asal limbah mempunyai kandungan serat kasar sekitar 4-5\% lebih tinggi dibandingkan pakan komersial. Wea

Tabel 4. Pengaruh perlakuan pakan terhadap konversi ransum ternak babi fase starter

\begin{tabular}{lccccc}
\hline \multirow{2}{*}{ Perlakuan } & \multicolumn{5}{c}{ Rataan konversi ransum } \\
\cline { 2 - 6 } & Minggu 1 & Minggu 2 & Minggu 3 & Minggu 4 & Minggu 1-4 \\
\hline P0 & 2,73 & 3,60 & 3,75 & 2,20 & 2,58 \\
P1 & 12,35 & 104,80 & 27,30 & 3,04 & 5,21 \\
P2 & 2,33 & 14,49 & 43,86 & 8,80 & 6,46 \\
P3 & 27,54 & 25,56 & 8,12 & 72,10 & 7,76 \\
Total SEM & 6,425 & 18,441 & 9,702 & 12,646 & 1,208 \\
Nilai P & 0,529 & 0,319 & 0,461 & 0,102 & 0,498 \\
\hline
\end{tabular}

P0, CP 551 (ransum komersial); P1, ransum campuran 3 bahan pakan limbah (limbah ikan, ampas tahu, limbah sayur); P2, ransum campuran 4 bahan pakan limbah (P1 + dedak padi); P3, ransum campuran 5 bahan pakan limbah (P2 + kulit keladi). 
[15] memberikan pakan limbah organik ke ternak babi umur 8 minggu juga mendapatkan PBB yang 50\% lebih rendah dari babi yang diberi pakan komersial meskipun konsumsi pakan didapatkan 8\% lebih tinggi. Ransum babi fase starter diharapkan mempunyai kandungan serat kasar tidak lebih dari 6\%. Walaupun begitu pada minggu ke 4 tampak ada lonjakan PBB pada P1 dan P2, ada kemungkinan bahwa pada minggu ke 3 sebagian besar ternak babi mulai dapat beradaptasi dengan kondisi pakan perlakuan yang berserat kasar tinggi.

Pertambahan berat badan pada ternak babi yang diberi P1, P2 dan P3 berturut-turut sebesar 91,61 g; 98,10 g, dan 52,63 g. Hasil yang sama dilaporkan oleh Tiro et al. [16], pertambahan bobot badan ternak babi di Distrik Wamena, Kabupaten Jayawijaya, Papua yang diberikan pakan limbah kebun (ubi jalar dan daun ubi jalar) berada pada kisaran $80 \mathrm{~g} \pm 20 \mathrm{~g}$. Tidak jauh berbeda dengan Mutua et al. [17] yang mendapatkan PBB untuk babi umur kurang dari 20 minggu yang diberikan pakan lokal sebesar 94,5 g/ekor/hari $( \pm 43 \mathrm{~g})$. Wea [15] juga mendapatkan PBB untuk ternak babi umur 8 minggu yang diberi $100 \%$ limbah organik pasar selama 32 minggu sekitar 141 g/ekor/hari. Hasil ini jauh dibawah kisaran normal pertambahan bobot badan ternak babi yang dilaporkan sebesar 200-700 gram/ekor/hari [16]. Kondisi ini menunjukkan bahwa ternak babi fase starter persilangan Batam dan Australia kurang memberikan respon pertumbuhan yang baik terhadap pakan campuran bahan pakan limbah yang diberikan. Tiro dan Fernandes [18] mendapatkan bahwa pertambahan bobot badan babi lokal dapat mencapai $0,1 \mathrm{~kg}$ per ekor per hari apabila dilakukan perbaikan pakan dan kandang. Hal ini mengimplikasikan bahwa faktor lingkungan maupun pakan (kuantitas dan kualitas) mempengaruhi pertumbuhan ternak babi.

Nangoy et al. [19] mendapatkan ada korelasi positif antara bobot lahir dengan pertambahan bobot badan. Babi dengan bobot lahir yang tinggi akan mempunyai PBB yang tinggi begitupun sebaliknya. Pada penelitian ini rataan berat awal ternak babi P0, P1, P2 dan P3 berturut-turut sebesar 7,99; 6,69; 6,97 dan $7,01 \mathrm{~kg}$. Apabila rataan berat awal ini dikaitkan dengan rataan PBB yang diperoleh $(381,19 \mathrm{~g} ; 91,61 \mathrm{~g} ; 98,10 \mathrm{~g}$ dan 52,63 g), hasilnya tidak mendukung pernyataan Nangoy et al. [19]. Hal ini menunjukkan bahwa berat awal berkorelasi positif dengan PBB apabila pakan mempunyai kandungan nutrisi yang tidak berbeda.

\section{Konsumsi ransum}

Rendahnya konsumsi ransum pada ternak babi yang diberi pakan campuran limbah sejak minggu pertama mengindikasikan bahwa sejak awal ternak sudah memberikan respon yang berbeda terhadap ransum perlakuan yang diberikan. Level serat kasar dalam ransum dapat mempengaruhi performa dan pertumbuhan ternak [20]. Serat kasar yang tinggi menyebabkan menurunnya palatabilitas

Tabel 5. Pengaruh perlakuan pakan terhadap total kecernaan pakan, kecernaan protein kasar (PK), kecernaan

\begin{tabular}{lcccc}
\multicolumn{5}{c}{ serat kasar (SK) dan kecernaan energi (\%) } \\
\hline \multirow{2}{*}{ Perlakuan } & Total kecernaan pakan & Kecernaan PK & Kecernaan SK & Kecernaan energi \\
\cline { 2 - 4 } & 74,11 & $(\%)$ & 73,49 \\
P0 & 12,08 & 78,41 & $67,29 \mathrm{~b}$ & 20,09 \\
P1 & 50,63 & $3,22^{\mathrm{a}}$ & 38,94 \\
P2 & 42,97 & 60,00 & $55,42^{\mathrm{b}}$ & 42,52 \\
P3 & 46,12 & 51,91 & $29,16^{\mathrm{ab}}$ & 8,523 \\
Total SEM & 8,726 & 5,587 & 9,021 & 0,187 \\
Nilai P & 0,106 & 0,283 & $0,043^{*}$ & \\
\hline
\end{tabular}

P0, CP 551 (ransum komersial); P1, ransum campuran 3 bahan pakan limbah (limbah ikan, ampas tahu, limbah sayur); P2, ransum campuran 4 bahan pakan limbah (P1 + dedak padi); P3, ransum campuran 5 bahan pakan limbah (P2 + kulit keladi).

a-bSuperskrip yang berbeda di dalam kolom yang sama menunjukkan berbeda nyata, ${ }^{*} \mathrm{p}<0,05$. 
pakan [20] yang berakibat pada turunnya konsumsi ransum dan akhirnya PBB. Palatabilitas merupakan faktor penting yang menentukan tingkat konsumsi [21]. Namun menurut peneliti tersebut ada kemungkinan bahwa dalam jangka panjang, efek dari palatabilitas dapat diatasi dengan kandungan nutrisi dalam pakan.

\section{Konversi ransum}

Tidak berbedanya nilai konversi ransum antar perlakuan pakan mengindikasikan bahwa kemampuan ternak babi dalam mengkonversi pakan menjadi daging tidak berbeda. Dengan kata lain dapat dikatakan bahwa tingginya PBB pada ternak babi fase starter yang diberi ransum komersial bukan karena ternak tersebut secara efisien merubah pakan menjadi daging tetapi karena ternak tersebut mengkonsumsi ransum lebih banyak.

Pada penelitian ini, nilai konversi ransum ternak babi yang diberi pakan asal limbah lebih rendah daripada nilai konversi ransum ternak babi yang diberi ransum komersial. Wea [15] juga menemukan konversi ransum yang lebih rendah pada ternak babi yang diberi $100 \%$ ransum limbah pasar dibandingkan ransum komersial. Menurut Patience et al. [4], penggunaan energi dalam ransum adalah dasar dari efisiensi pakan meskipun banyak faktor-faktor lain yang ikut mempengaruhi efisiensi pakan. Konsumsi ransum yang rendah pada P1, P2, dan P3 secara tidak langsung mengimplikasikan rendahnya penggunaan energi ransum. Meskipun konversi ransum antar pakan perlakuan tidak berbeda nyata, namun secara numerik nilai konversi ransum meningkat paralel dengan menurunnya konsumsi ransum.

\section{Total kecernaan pakan dan nutrien}

Menurut Schneider and Flatt [13], kecernaan adalah banyaknya bahan pakan yang dicerna dalam saluran pencernaan. Nilai kecernaan tinggi mencerminkan besarnya sumbangan nutrisi tertentu pada ternak, sedangkan pakan dengan nilai kecernaan rendah menunjukkan bahwa pakan tersebut kurang mampu menyuplai nutrisi untuk hidup pokok maupun tujuan produksi ternak. Semakin tinggi kecernaan suatu pakan, ternak akan terstimulir untuk makan semakin banyak. Tidak berbedanya total kecernaan pakan pada penelitian ini menekankan bahwa tingginya PBB pada ternak babi yang diberi pakan komersial bukan karena kecernaan pakan yang lebih baik tetapi lebih disebabkan karena tingginya konsumsi ransum.

Kecernaan serat kasar pada suatu bahan pakan sangat berpengaruh terhadap kecernaan pakan, serat kasar yang tinggi akan menurunkan nilai kecernaan karena laju digesta pakan yang cepat [20]. Tidak berbedanya kecernaan SK antara P2 dan P3 dengan $\mathrm{P} 0$ tidak diketahui karena kandungan serat kasar P2 dan P3 lebih tinggi daripada P0 $(10,24,11,5$ vs $6 \%)$. Alasan yang dapat dikemukakan kemungkinan karena adanya interaksi antara serat kasar dengan komponen nutrisi yang lain dalam ransum. Interaksi antara serat kasar dengan komponen nutrisi yang lain dalam ransum dapat memodifikasi karakteristik fisik dan kimia dari serat kasar [22].

\section{KESIMPULAN}

Pemberian campuran bahan pakan limbah pada ternak babi fase starter mempunyai efek negatif terhadap performa tetapi tidak berdampak pada kecernaan pakan. Tingginya serat kasar diduga menurunkan palatabilitas yang berdampak pada menurunnya konsumsi ransum dan PBB. Interaksi serat kasar dengan komponen nutrisi lain dalam ransum dapat memodifikasi karakteristik fisik dan kimia dari serat kasar yang dapat berdampak pada kecernaan serat kasar.

\section{KONFLIK KEPENTINGAN}

Tidak ada konflik kepentingan terkait keuangan maupun materi yang dibahas dalam naskah.

\section{UCAPAN TERIMA KASIH}

Ucapan terima kasih disampaikan kepada Bapak Fransiscus Tanuardus, ARO-M Angkasa Mulyono, Amban, Manokwari yang telah membantu peneliti dalam penyediaan 
kandang penelitian sehingga penelitian dapat berjalan lancar.

\section{DAFTAR PUSTAKA}

1. Iyai, D., D. Woran, and I. Sumpe. 2010. Clustering, and principal component analyses of constraints in smallholding pig keeping systems in Manokwari, Indonesia. Anim. Prod. 12:199-206.

2. Suroto, H. 2014. Babi dalam budaya Papua (Pig in the Papua culture). J. Pen. Arkeo. Papua dan Papua Barat. 6:37-44.

3. BPS Papua Barat. 2015. Papua Barat dalam angka. Badan Pusat Statistik, Manokwari.

4. Patience, J. F., M. C. Rossoni-Serão, and N.A. Gutiérrez. 2015. A review of feed efficiency in swine: biology and application. J. Anim. Sci. Biotechno. 6:33-49. doi:10.1186/s40104-015-0031-2.

5. Budaarsa, K., A. W. Puger, and I. M. Suasta. 2016. Eksplorasi komposisi pakan tradisional babi Bali. Majalah Ilmiah Peternakan. 19:6-11. doi:10.24843/MIP.2016.v19.i01.p02.

6. Septian, F., D. Kardaya, and W. D. Astuti. 2011. Evaluasi kualitas silase limbah sayuran pasar yang diperkaya dengan berbagai aditif dan bakteri asam laktat. Jurnal Pertanian. 2:117-124. doi:10.30997/jp.v2i2.576.

7. Saud, R. H., V. R. W. Rawung, J. M. Soputan, and M. T. R. Lapian. 2019. Penampilan produksi ternak babi grower sampai finisher yang menggunakan tepung limbah ikan cakalang sebagai pengganti sebagian konsentrat dalam ransum. Zootek. 39:23-32. doi:10.35792/zot.39.1.2019.22109.

8. Budaarsa, K., G. E. Stradivari, I. P. G. A. S. K. Jaya, I. G. Mahardika, A. W. Puger, I. M. Suasta, and I. P. A. Astawa. 2015. Pemanfaatan ampas tahu untuk mengganti sebagian ransum komersial ternak babi. Jurnal Ilmiah Peternakan Universitas Udayana. 18:226-239.

9. Pattiselanno, F. and D. Iyai. 2005. Peternakan babi di Manokwari: mempertahankan tradisi dan meningkatkan taraf hidup. Salam. 13:24-25.
10. Lekitoo, M. N., S. Hartini, S. Lumatauw, D. D. Rahardjo, S. Y. Randa, and T. W. Widayati. 2014. Studi potensi pakan lokal untuk pengembangan peternakan babi di Kabupaten Manokwari. Laporan Penelitian. Kerjasama Fak. Peternakan Perikanan dan Ilmu Kelautan Universitas Negeri Papua dan Dinas Peternakan dan Ketahanan Pangan Prov. Papua Barat. Manokwari.

11. Hartini, S., M. N. Lekitoo, S. Lumatauw, D. D. Rahardjo, S. Y. Randa, T. W. Widayati, and R. Siregar. 2015. Nutritive value of grower pig ration using local feeds in West Manokwari District, Manokwari. Proc. of 5th Int. Conf. on Sustain. Anim. Agric. for Develop. Count. 5:145-148.

12. Noblet, J. and J. M. Perez. 1993. Prediction of digestibility of nutrients and energy values of pig diets from chemical analyses. J. Anim. Sci. 71:3389-3398. doi:10.2527/1993.71123389x.

13. Schneider, B. H. and W.P. Flatt. 1975. The evaluation of feeds through digestibility experiment. University of Georgia Press, New York.

14.SPSS. 2007. SPSS 16.0 Command Syntax Reference. Inc. Chicago IL, Chicago.

15. Wea, R. 2010. Performans produksi ternak babi yang mengkonsumsi limbah organik pasar. Partner. 17:127-135.

16. Tiro, B. M. W., P. A. Beding, and R. H. S. Lestari. 2019. Profil peternakan babi di Distrik Wamena, Kabupaten Jayawijaya, Papua. Jurnal Pertanian Agros. 21:9-18.

17. Mutua, F. K., C. Dewey, S. Arimi, W. Ogara, M. Levy, and E. Schelling. 2012. A description of local pig feeding systems in village smallholder farms of Western Kenya. Trop. Anim. Health Prod. 44:1157-1162. doi:10.1007/s11250-011-0052-6.

18. Tiro, B. M. W. and P. T. Fernandes. 2007. Kajian teknologi budidaya dan pengaruhnya terhadap penampilan ternak babi. Pros. Sem. Nas. BBPP. Teknologi Pertanian. 574-579.

19. Nangoy, M. M., M. T. Lapian, M. Najoan and J. E. M. Soputan. 2015. Pengaruh bobot lahir dengan penampilan anak babi sampai disapih. Zootek. 35:138-150. 
doi:10.35792/zot.35.1.2015.7223.

20.Siagian, P. H., S. Natasamita, and P. Silalahi. 2005. Pengaruh substitusi jagung dengan corn gluten feed (CGF) dalam ransum terhadap kualitas karkas babi dan analisa ekonomi. Media Peternakan. 28:100-108.

21. Solà-Oriol, D., E. Roura, and D. Torrallardona. 2011. Feed preference in pigs: Effect of selected protein, fat, and fiber sources at different inclusion rates. J. Anim. Sci. 89:3219-3227. doi:10.2527/jas.2011-3885.

22. Hartini, S. and M. Choct. 2010. The effect of non-starch polysaccharides derived from different grains on performance and digestive activity in laying hens. J. Indonesian Trop. Anim. Agric. 35:95-100. doi:10.14710/jitaa.35.2.95-100. 